\title{
Classroom Environment, Scientific Creativity, Self-Concept as Predictors of Achievement in Science of Vii Standard Sc $\backslash S t$ and Non SclSt Students
}

\author{
Dr. M. Narayana Swamy, Ramesha \\ Associate Professor, Research Scholar \\ Department of Education Bangalore University Bangalore-560 056
}

\begin{abstract}
Education is very important for the development of an individual as well as for the society as a whole. It helps an individual in his all round and integrated development, at macro level it provides well trained and highly skilled manpower. Which is vital for the progress of the society in all spheres-Economic, Social and Political?
\end{abstract}

Key Words: Classroom environment, scientific creativity, self concept and achievement in science a experimental study.

\section{Introduction}

In the education primary education is the important the basic foundation at all levels of education. In the primary Education VII standard is the turning point in student life. The great importance of science teaching in primary schools is elucidated by considering the following.

1. The school in general, should teach students basic knowledge of the science as well as fundamental principles of scientific thinking and problem solving the aim is to spark the interest of the student in the science in and prevent them from disliking and rejecting the possibly scientific profession as the result of negative experiences at school.

2. Especially who student later work in a field un related to the sciences have to have a foundation for understanding the world that also them to make informed decisions.

3. In this recorded primary education is especially important Teaching lessons that deals with scientific phenomenon can form the foundation for a permanent interest in the sciences.

Achievement in Science occupies a very prominent place in curriculum both at elementary and secondary stages of Education in India, continuous advances in scientific and Technological research has led to the growth and greater application of science in contemporary society.

Accordingly the Achievement in Science becomes a priority area in education, both at the compulsory education level as well as the Specialization, Science Education is supposed to perform a two fold task, the prime objective in individualistic perspective, is the cultivation of a scientific temper, which includes the spirit of enquiry, a disposition to reason logically and Dispassionately, a habit of judging beliefs and opinions on available evidence readiness to reject unfounded theories and principles, the courage to admit facts, howsoever, recognizing the limits of reasoning power itself, it is also expected of science education that it would give individuals a firm grasp of the concepts and process of science and impart them the ability to use the scientific method of problem solving and the techniques of observation and experimentation in handling problem of comprehension life, at the societal level, one of the major objective of science education is to equip individual to participate in the creation of society which is free from poverty, hunger, disease and Social evils such as violence, exploitation, oppression, etc.

Researches in science education have to be reviewed in the context of these aims and objectives, in the world of today where knowledge is being multiplied exponentially science education will not be able to justify itself by remaining merely contented with the objective of imparting a certain quantum of scientific knowledge.

\section{Need for the Study}

Achievement in science is very important goal in the educational process both at elementary and secondary, Achievement in science is the product variable which gets toned up or bogged down by the positive and negative influence of a host of independent variables.

It is the amount of Achievement in science provided in one academic year, Achievement in science is something accomplished especially by superior ability in one calendar year of an institution, it is the special effort or great deed or an act of achieving accomplishments - Webster (1997). Achievement is science always depends on many external and internal factors many studies have been done to see dependence of Achievement in science with school atmosphere and personality traits and proved that it is dependent significantly. In every 
class Achievement in science is different from student to student, there is a cry among the various sections of the society for high accomplishment of academic Achievement.

India is at a crucial stage in development and role of Achievement in science at the primary level is associated with the factor like classroom environment scientific creativity, self-concept type of school, gender, caste and host of other factors, classroom environment play an important role in motivation for teacher and learner classroom is both a kind of shelter and a stage, it brings together children and teachers on the day today contents, learning work hard having fun and growing up, it focuses attention and is a focus of attention, classroom is the place where every participant applies three his i.e. head, heart and hand for realizing desired goal, classroom environment is a unique face to face group marked by interpersonal relationship among its members.

These interpersonal relationships essentially include teacher-student and peer relationship the relationship general atmosphere within which the academic activities takes place is influenced by these social relationships, therefore classroom environment is taken as a variable in the study.

Scientific creativity is a process of sensing the problem in the field in science, thinking generate many different novel and relevant solution of the problem and finally communicating them, it is creative thinking through the medium of science therefore researcher considers scientific creativity as one of the variable in the study.

\section{Objectives of the study}

Keeping the above said points in view, the study is undertaken with the following objectives.

1. To know the relationship between the Achievement in science of VII standard SC IST students with classroom environment.

2. To know the relationship between Achievement in science of VII standard non SCIST students with classroom environment.

3. To know the relationship between Achievement of VII standard SC $\backslash S T$ students with scientific creativity.

4. To know the relationship between Achievement of VII standard non SCIST students with scientific creativity.

5. To know the relationship between Self-concept and Achievement in science of VII standard SCIST students.

\section{Hypotheses}

- There is no significant relationship between classroom environment and Achievement in science of VII Standard SCIST and non-SCIST students.

- There is no significant Predictors of classroom environment on Achievement in science of VII Standard SCIST and non-SCIST students.

- There is no significant relationship between scientific creativity and Achievement in science of VII Standard SCIST and non-SCIST students.

- There is no significant contribution between scientific creativity and Achievement in science of VII Standard SCIST and non-SCIST students.

- There is no significant relationship between self-concept and Achievement in science of VII Standard SCIST and non-SCIST students.

- There is no significant contribution between self-concept and Achievement in science of VII Standard SCIST and non-SCIST students.

\section{Methodology}

The authenticity of results obtained depends upon the true representatives of the sample selected, a sample is a small portion of the population for analysis, it should be representative of the population. Therefore sample is selected deliberately so that the influence of chance or probability can be estimated.

The efficiency of an investigation depends largely on the proper selection of the sample on which the test is to be administered the investigator used the stratified proportionate random sampling method for drawing sample, this is a technique resigned to ensure representative sample and avoid bias by the use of random selection within each subgroup. The population for the study consists of students VII Standard from different schools of Bangalore Urban and Rural Districts.

\section{Tools for Research}

The following scales were used in this study for the collection of data.

1. Achievement in Science Scale (AISS): Achievement in science scale was developed and standardized by Dr. M. Narayanaswamy and Ramesha (2008) was used to assess the Achievement in science. 
2. Classroom Environment: (CRES): Classroom environment was developed and standardized by Dr. M. Narayanaswamy and Ramesha (2008) was used to assess the classroom environment.

3. Scientific Creativity: (VTSC): Scientific creativity was developed and standardized by Dr. V.P. Sharma and Dr. J.P. Shukla, was used to asses the scientific creativity.

4. Self - concept: (SCS): Self - Concept inventory was developed by Dr. Ahluwalia was used to assess the self-concept of the students.

5. Background Variables: A self-developed information proforma was developed for collecting information on background variables, i.e. gender, type of management, area of the school, caste of the students.

\section{Limitations of the Study}

The investigation has certain limitations that have been raised from the point of view of practicability of cost, effort, time factor, etc.

1. The present study is confined to VII Standard students of few schools of Bangalore Urban and Rural districts.

2. Only a few independent variables were considered for the study.

3. Only a few schools were selected.

4. The present study was conducted only for primary schools.

5. The present study confines only to classroom environment, scientific creativity self-concept and few background variables like gender, types of management, area of the school, as parameters to measure the Achievement in science of VII Standard students of Bangalore Urban and Rural students.

6. The Achievement in science had only 25 multiple choice item.

\section{Major Findings of the Study}

1) Achievement in science had significant relationship with all the components of class room environment. Further regression analysis revealed that dimensions of class room environment like "pupil-pupil relation ship out side the school". The "language" used by the Teacher, "Educational technology", "pupil-pupil relation ship with in the school", "attitude of a teacher towards students studies", "use of new teaching methods", "General attitude of teachers towards student", "utility of time table", "wiehgtage to cocurricular activities" are best predictors of the Achievement of in science of the VII standard students.

2) All the Tasks of scientific creativity had positive influence over Achievement in science of the VII standard students. As all the tasks of the scientific creativity positively correlated with the Achievement in science. Further regression analysis revealed as revealed that tasks of scientific creativity like unusual test, Consequent test, just think why test are best predictors of the Achievement in science of VII standard students.

3) All the components of the Self-concepts were significantly and positively correlated with the Achievement in science. Further regression analysis revealed that Dimension like intellectual and school status, "happiness and satisfaction", "behavior and anxiety" are best predictors of the Achievement in science of the VII standard students.

4) Non SCIST students scored higher than the SclSt students in Achievement in science

5) Gender had no significant influence over Achievement in science

6) Students from the urban area excelled when compared to the rural area students in Achievement scores in science.

7) SclSt Students from rural area had the least Achievement in science.

8) Student studying in unaided schools had higher Achievement in science when compared to the student studying in aided school.

9) For SclSt students the best predicted variables were best predictors of Achievement in science were " Pupil - Pupil Relation with in the school", "Intellectual and School Status", "General Attitude of Teacher", "Educational Technology", "Pupil - Pupil Relation out side the school", "Unusual Uses Test (TASK2)".

10) For non SCIST students the best predicted variables were, "Intellectual and School Status", "Pupil - Pupil Relation out side the school", "Consequences Test (TASK1)", "Attitude of Teacher towards pupils Studies", "General Attitude of Teacher", "Language use by the teacher", "Pupil -Pupil Relation within the school", "Behavior", "Use of new methods", "New Relationship Test (TASK3)".

\section{Educational Implications}

- By making students attitude favorable towards science.

- By arranging diagnostic and remedial classes.

- By determining objectives in behavioural terms and applying objective based evaluation.

- By properly distributing the work to the science teachers. 
- By finding the learner's difficulty.

- By providing planned assignments.

- By providing opportunity of self-activity.

- By suggestions for ways of self-study.

- By developing the scientific attitude.

- Help the students in organizing science club, science quiz.

- Help the students to build science vocabulary by having them written in their note books the list of new words and words that have caused difficulty illustrating each and using them in sentences.

- Help the student in organizing browsing sessions in the library and internet.

- Help the students in organizing a student's symposium on the life and work of scientists on their birthdays.

- Help the students in having brainstorming session on difficult science concepts.

\section{Suggestions for further study}

1. The study may be extended to a larger sample drawn from the state of Karnataka as a whole.

2. The study of Achievement in science may be under taken by incorporating variable like semotional intelligence, interest, aptitude.

3. The study may be extended to the secondary schools, PUC and other levels of education.

4. Sophisticated analysis method like UNCOVA and discriminate functional analysis may be used.

5. The experimental design can be under taken to examine the effect of treatment variables on the Achievement in science.

\section{Bibliography}

[1]. Abrami and et. al, A Study on the group outcome. The Relationship between group learning outcome, Attributional Style, Academic (Mathematics) Achievement and Self-Concept (1992)

[2]. B.P. Varma (1990) "Cognitive ability academic Achievement and study habits of socially advantaged and disadvantaged adolescent students", The Progress of Education, Vol. LXIV (12), July 1990.

[3]. Boliang, Guo; Lei, Zhang; Chinese 18(10), Mental Health Journal, Vol. Oct. 2004, pp.708-710. [Journal Article]

[4]. Brock, Laura L.; Nishida, Tracy K.; Chiong, Cynthia; Journal of School Psychology, Vol. 46(2), Apr 2008. pp.129-149. [Journal Article] Abstract:

[5]. Buch M.B., Education: "A Survey of research in Education CASE, MS University, Baroda, 1974.

[6]. Castor, Stacey Elizabeth; Dissertation Abstracts International: Section B: The Sciences and Engineering, Vol. 57(10-B), Apr 1997, pp. 6603. Abstract:

[7]. classroom environment', Set, Vol. 1, no. 9, pp. 1-4.

[8]. Dr. Milind Sahastrabuddhe, Sujata Srivasta "School Education of SC $\backslash$ ST in India, "Critical Management Issue", New Frontiers in Education, Vol. XXVIII (3), July-sept. 1998. 